\title{
Linear Alkylbenzene Sulfonates in the Groundwater and Surface Waters: Ergene Basin Case Study
}

\author{
Füsun Ekmekyapar ${ }^{1}$ and Zehra Barut ${ }^{2}$ \\ 1. Department of Environmental Engineering, Çorlu Engineering Faculty, Namık Kemal University, Tekirdă̆ 59860, Turkey \\ 2. Graduate School of Natural and Applied Sciences, Namık Kemal University, Tekirdağ 59860, Turkey
}

\begin{abstract}
Ergene Basin is one of the most important industrial centers due to the geographical location in Turkey. Uncontrolled and rapidly increasing industrialization brings together a large number of environmental problems in the basin. In this study, pollution was investigated in the water samples taken at time intervals and different parts of groundwater and surface water resources located within Ergene Basin by methylene blue anionic surfactants (MBAS) analysis method. Turbidity, temperature, pH, electrical conductivity (EC), concentrations of total $\mathrm{P}$ and linear alkylbenzene sulfonates (LAS) were simultaneously determined in the investigated water resources. The results were compared with the Turkish Water Pollution Control Regulation specified in the Quality Criteria of the Inland Water Resources according to their class. The total P and LAS concentrations of surface waters are generally higher than groundwater. In terms of LAS concentrations, the groundwater is I-II class and the surface water is II-IV class.
\end{abstract}

Key words: Surface water, groundwater, surfactant pollution, linear alkylbenzene sulfonates, methylene blue anionic surfactants.

\section{Introduction}

Recently, the contamination of aquatic environments with organic compounds (e.g., pharmaceuticals, surfactants, endocrine disruptors and polymers) has become the focus of increasing regulation and public concern due to their potential, but still unknown, negative effects on the wildlife that inhabit these ecosystems [1].

Many aquatic systems are subjected to the influence of both urban and industrial wastewater discharges, which are among the main sources of organic contaminants in the environment. Among many other chemicals, synthetic surfactants can be found at relatively high concentrations in wastewater due to their extensive use in a wide variety of applications: paints, pesticide formulations, wetting agents, personal care products and especially, active ingredients of detergents in cleaning products [2].

Anionic surfactants are widely used in both domestic and industrial applications, particularly in

Corresponding author: Füsun Ekmekyapar, associate professor, research field: diffuse pollution. laundry detergents. Since, by the nature of their uses, they are destined to be discharged to wastewater, the major surfactants have been extensively studied in term of their environmental properties, including biodegradation characteristics and toxicity to aquatic organisms [3].

Urban wastewater discharges and industrial activities were identified as the main sources for these compounds. Once used, surfactants are discharged via wastewater treatment plants (WWTPs) into aquatic environments [4]. They may enter the aquatic environment when raw or partially treated sewage is discharged [5]. In urban areas of the developing world, poor provision of wastewater treatment means that municipal and household wastewater is discharged directly to receiving waters. The largest group of anionic surfactants is linear alkylbenzene sulfonates (LAS) [6].

LAS are commonly contained in detergent waste. As an anionic surfactant, LAS consists of hydrophobic and hydrophilic group bearing negative charge [7]. Likewise, LAS is one of the most common organic chemicals used in personal care products. Due to its 
widespread use, it has been detected at $5 \mu \mathrm{g} / \mathrm{L}[8]$ in groundwater, 14-155 $\mu \mathrm{g} / \mathrm{L}$ [9], 11-342 $\mu \mathrm{g} / \mathrm{L}$ [6], $2.3-2,406.8 \mu \mathrm{g} / \mathrm{L}[10]$ in river water and $124 \mathrm{mg} / \mathrm{kg}$ [1] in sediment.

As the fast industrial development in the Ergene Basin, the organic chemicals pollution is common. There are mainly textile factories, white goods, glass, oil, food and chemical factories [11]. These factories in the basin discharge their waste into the Ergene River and its branches. These activities, as well as population growth, have substantially increased the burden of contamination. Therefore, the environmental quality in aquatic system of the Ergene River has direct and significant effects on drinking water safety of the city, stability and biodiversity of the aquatic ecosystem and so on.

No studies have been reported on the Ergene Basin on the subject of surfactants pollution. Surface water and groundwater in the basin are constantly subject to pollution caused by the rapid increase in population and the intensity of agricultural and industrial activities. Monitoring of surface waters and groundwater is necessary to establish the levels of contamination in terms of surfactants. Further study of the surfactant pollution is needed to uncover contamination profile in the basin.

The present study aimed to investigate the seasonal changes in some physical-chemical properties of surface waters and groundwater in the Ergene Basin, and determine the concentration and distribution of LAS in surface waters and groundwater in the Ergene Basin.

\section{Materials and Methods}

\subsection{Study Area}

Ergene River basin is located on the Northwest of Turkey at the Thrace Region. Three provinces are located in the basin. Being the largest industrial settlement in the south section of the Ergene River basin, Tekirdağ plays a key role not only in storing water, agricultural irrigation, water supply and climatic regulation, but also in producing a good deal of marketable grain and fishing. One of the main activities in the city is agriculture. Agricultural products, such as cereals and sunflower, are the most frequently cultivated [11]. In addition, uncontrolled industrial development, population growth and migrations in the basin have enriched water resources in terms of organic chemicals.

\subsection{Sampling and Sample Preparation}

Seasonal water samples were taken at three sampling sites and six samples were taken from each site. March, April and May samples were taken in 2014. October, November and December samples were taken in 2015. Samples of the stream-surface microlayer and groundwater were collected along the Çerkezköy (C), Muratlı (M) and Uzunköprü (U), which are richer with anthropogenic activities than the north of Ergene River basin (stations C, M and U), as shown in Fig. 1.

Samples which were put in the acid-rinsed polyethylene containers were immediately taken to the laboratory. Field water sampling and measurements followed standard methods [12]. All chemicals were used of the highest purity available (Merck), and all glassware and laboratory equipment were carefully cleaned before using with $\mathrm{HCl}$ to minimize potential contamination.

Water samples were collected by using sample bottles of $1,000 \mathrm{~mL}$ for surfactants and $500 \mathrm{~mL}$ for physical-chemical parameters. The samples were stored at $+4{ }^{\circ} \mathrm{C}$ until they were analyzed. Samples were analyzed for five physicochemical parameters: temperature, $\mathrm{pH}$, electrical conductivity (EC), turbidity, total P and surfactant (LAS).

The samples were collected in plastic bottles and brought to the laboratory where filtered. Temperature, $\mathrm{pH}$ and EC were measured directly after collection. They were also monitored in the samples using a multi-parameter measurement instrument (WTW 3430) after appropriate calibrations with standard buffer solutions. Values of turbidity were measured using 


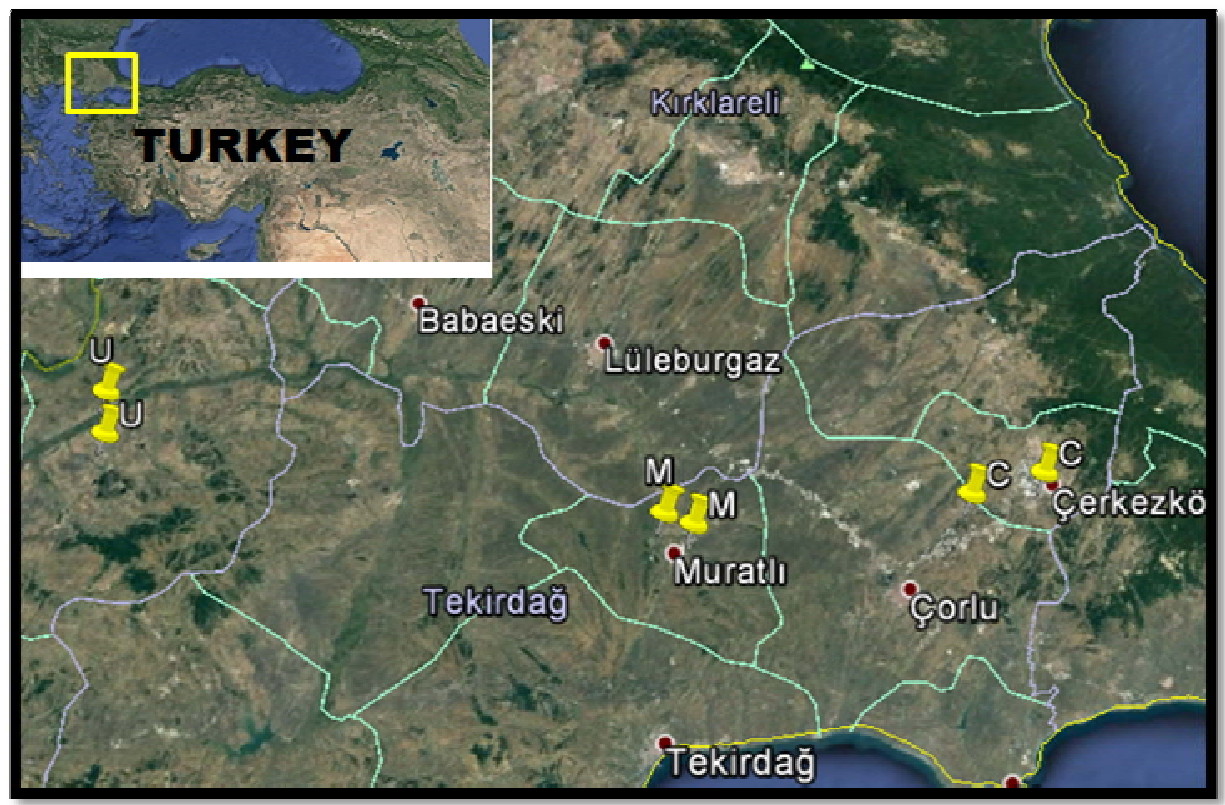

Fig. 1 Map showing samples taken from groundwater and surface waters.

turbid meter (VELP SCIENTIFICA-TB1). Physical-chemical properties and total $\mathrm{P}$ were determined by standard methods [12].

\subsection{Methylene Blue Active Substances (MBAS) for Analysis of the Samples}

The samples were filtered using $0.45 \mu \mathrm{m}$ Whatman GF/C glass microfiber filters. Total $\mathrm{P}$ and surfactants LAS were measured using UV Spektrofotometre (HACK-DR5000) in Laboratory of Yeşil Beyaz Quality and Environment in Tekirdağ [13].

The determination of low levels (typically 0-20 $\mathrm{mg} / \mathrm{L}$ ) of anionic surface active materials by MBAS as described by ISO 7875-1 [14] is used in the analysis of a wide range of samples including surface and potable waters. Higher concentrations can be diluted for analysis.

Methylene blue dyes were used to determine LAS. $20 \mathrm{~mL}$ of the sample solution was put into a $40 \mathrm{~mL}$ vial (vial A) equipped with a screw-cap and Teflon liner. Then $2 \mathrm{~mL}$ alkaline buffer and $1 \mathrm{~mL}$ natural methylene blue solution, followed by $5 \mathrm{~mL}$ of chloroform, were added to vial $\mathrm{A}$ in that order. The vial was subsequently sealed using a holed screw-cap and Teflon liner, before being vigorously shaken using a vortex mixer for $2 \mathrm{~min}$. After shaking, the vial was left to await phase separation. The screw-cap was loosened to release the pressure inside. Once the two phases were separated, a Pasteur pipette was used to transfer the chloroform layer into a new vial (vial B) containing $22 \mathrm{~mL}$ ultra-pure water and $1 \mathrm{~mL}$ acid methylene blue solution. Vial B was then shaken using a vortex mixer for $2 \mathrm{~min}$. The cap was loosened for a few seconds and then re-tightened. After the chloroform had completely separated from the water (after about $2 \mathrm{~min}$ ), the chloroform layer was collected using a Pasteur pipette and put into a $10 \mathrm{~mm}$ quartz cell. The absorbance of the chloroform phase was measured with ultra-violet spectrophotometer at a wavelength of $650 \mathrm{~nm}$.

\section{Results and Discussion}

\subsection{Groundwater}

Physical-chemical properties, total $\mathrm{P}$ and LAS determined in the samples of groundwater are presented in Table 1 . The temperature values range from $17.5{ }^{\circ} \mathrm{C}$ to $22.8^{\circ} \mathrm{C}$ and the $\mathrm{pH}$ values are in 
range of 7.1-8.9. The $\mathrm{pH}$ values of Muratl groundwater are generally higher than other groundwater samples. The turbidity and EC values range from $0.1 \mathrm{NTU}$ to $3.75 \mathrm{NTU}$ and $310 \mu \mathrm{S} / \mathrm{cm}$ to $729 \mu \mathrm{S} / \mathrm{cm}$, respectively. The EC and temperature values of Çerkezköy groundwater are generally higher than other groundwater samples. In this study, the values of $\mathrm{pH}$, temperature, turbidity and $\mathrm{EC}$ are within an acceptable range for irrigation and drinking water according to Turkish Standard Regulation of Water Pollution Control [15] and EC Drinking Water Directive [16]. The total $\mathrm{P}$ and LAS concentrations are generally low in groundwater. The highest concentration of total P and LAS were measured as $0.65 \mathrm{mg} / \mathrm{L}$ and $0.37 \mathrm{mg} / \mathrm{L}$ in Muratl groundwater (M2-sites) in April, 2014, respectively.

In a similar research, the total concentrations of LAS is $>1,000 \mathrm{mg} / \mathrm{L}$ at the groundwater in Spain. Groundwater may suffer pollution from many sources, including water leakage from sewer and septic systems, seepage from rivers and application of fertilizers and agrochemicals, among others. As a result, a wide range of organic pollutants can be found in aquifers posing a risk to groundwater quality [17].
The values of turbidity and EC in groundwater are lower than the surface waters (Figs. 2 and 3). The highest value of turbidity was measured in Uzunköprü surface water (U4) as 43.6 NTU. The highest EC value was measured in Çerkezköy surface water (C4) as $5,080 \mu \mathrm{S} / \mathrm{cm}$. The wastewater and sludge discharge in both sites are very high. For this reason, they may be higher than other sites.

\subsection{Surface Waters}

Physical-chemical properties, total $\mathrm{P}$ and LAS determined in the surface waters are presented in Table 2. The temperature and $\mathrm{pH}$ values are in ranges of $12-24{ }^{\circ} \mathrm{C}$ and $7.2-8.2$, respectively. The temperature and $\mathrm{pH}$ values of Uzunköprü surface waters are generally higher than other surface waters. The turbidity and EC values range from 13.4 NTU to 43.6 NTU and $430 \mu \mathrm{S} / \mathrm{cm}$ to $5,080 \mu \mathrm{S} / \mathrm{cm}$. The EC values of Muratlı surface waters are generally higher than other surface waters. Because the surface waters of Muratlı have collected domestic and industrial wastewater. Textile and oil factories are located intensively in the site of Muratl. The values of turbidity are very high in Uzunköprü surface waters.

Table 1 Some physico-chemical properties, concentrations of total $P$ and LAS in groundwater.

\begin{tabular}{|c|c|c|c|c|c|c|c|c|}
\hline $\begin{array}{l}\text { Sample } \\
\text { code }\end{array}$ & Name of sample & Date & $\mathrm{T}\left({ }^{\circ} \mathrm{C}\right)$ & $\mathrm{pH}$ & $\begin{array}{l}\text { Turbidity } \\
\text { (NTU) }\end{array}$ & $\begin{array}{l}\mathrm{EC} \\
(\mu \mathrm{S} / \mathrm{cm})\end{array}$ & $\begin{array}{l}\begin{array}{l}\text { Total P } \\
(\mathrm{mg} / \mathrm{L})\end{array} \\
\end{array}$ & $\begin{array}{l}\mathrm{LAS} \\
(\mathrm{mg} / \mathrm{L})\end{array}$ \\
\hline $\mathrm{C} 1$ & \multirow{6}{*}{ Çerkezköy } & March-2014 & 18.7 & 7.3 & 0.22 & 589 & $<0.01$ & $<0.01$ \\
\hline $\mathrm{C} 2$ & & April-2014 & 18.3 & 7.3 & 1.21 & 729 & $<0.01$ & $<0.01$ \\
\hline $\mathrm{C} 3$ & & May-2014 & 20.7 & 7.3 & 0.20 & 705 & 0.05 & $<0.01$ \\
\hline $\mathrm{C} 4$ & & October-2015 & 22.8 & 7.1 & 0.10 & 680 & 0.06 & $<0.01$ \\
\hline $\mathrm{C} 5$ & & November-2015 & 20.9 & 7.2 & 0.21 & 658 & $<0.01$ & 0.19 \\
\hline $\mathrm{C} 6$ & & December-2015 & 18.3 & 7.2 & 0.39 & 310 & $<0.01$ & $<0.01$ \\
\hline M1 & \multirow{6}{*}{ Muratlı } & March-2014 & 18.2 & 7.5 & 0.40 & 420 & $<0.01$ & $<0.01$ \\
\hline M2 & & April-2014 & 17.5 & 8.0 & 2.51 & 540 & 0.65 & 0.37 \\
\hline M3 & & May-2014 & 19.0 & 7.8 & 0.35 & 580 & $<0.01$ & $<0.01$ \\
\hline M4 & & October-2015 & 25.0 & 8.9 & 3.75 & 516 & $<0.01$ & $<0.01$ \\
\hline M5 & & November-2015 & 17.6 & 8.9 & 0.07 & 496 & 0.1 & 0.16 \\
\hline M6 & & December-2015 & 19.4 & 7.2 & 0.14 & 499 & $<0.01$ & $<0.01$ \\
\hline U1 & \multirow{6}{*}{ Uzunköprü } & March-2014 & 18.3 & 7.2 & 0.81 & 680 & $<0.01$ & $<0.01$ \\
\hline U2 & & April-2014 & 20.7 & 7.5 & 0.30 & 653 & $<0.01$ & $<0.01$ \\
\hline U3 & & May-2014 & 21.0 & 7.2 & 0.60 & 640 & $<0.01$ & $<0.01$ \\
\hline U4 & & October-2015 & 21.3 & 7.4 & 0.27 & 593 & 0.11 & $<0.01$ \\
\hline U5 & & November-2015 & 20.3 & 7.2 & 0.03 & 310 & $<0.01$ & $<0.01$ \\
\hline U6 & & December-2015 & 19.9 & 7.2 & 0.21 & 513 & $<0.01$ & $<0.01$ \\
\hline
\end{tabular}




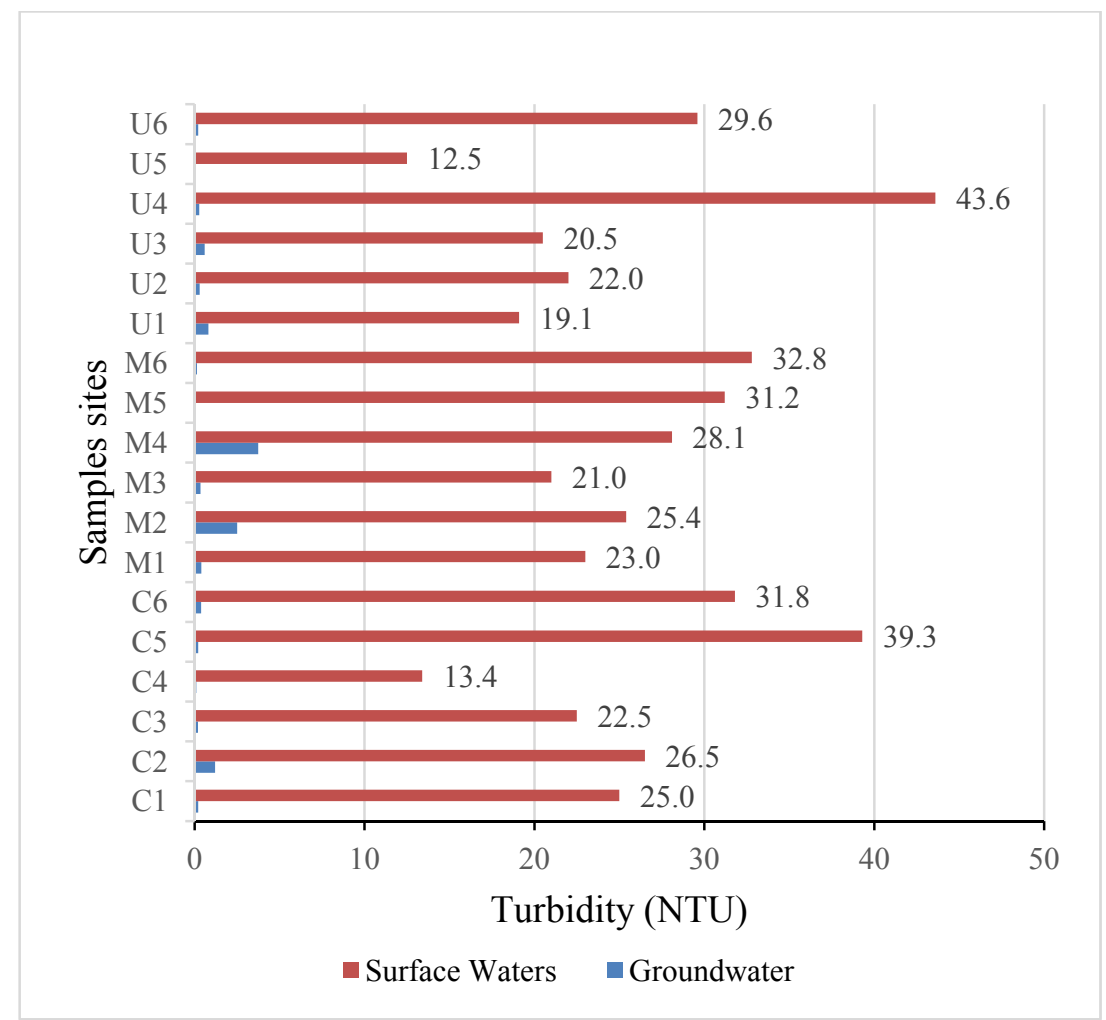

Fig. 2 The values of turbidity in groundwater and surface waters.

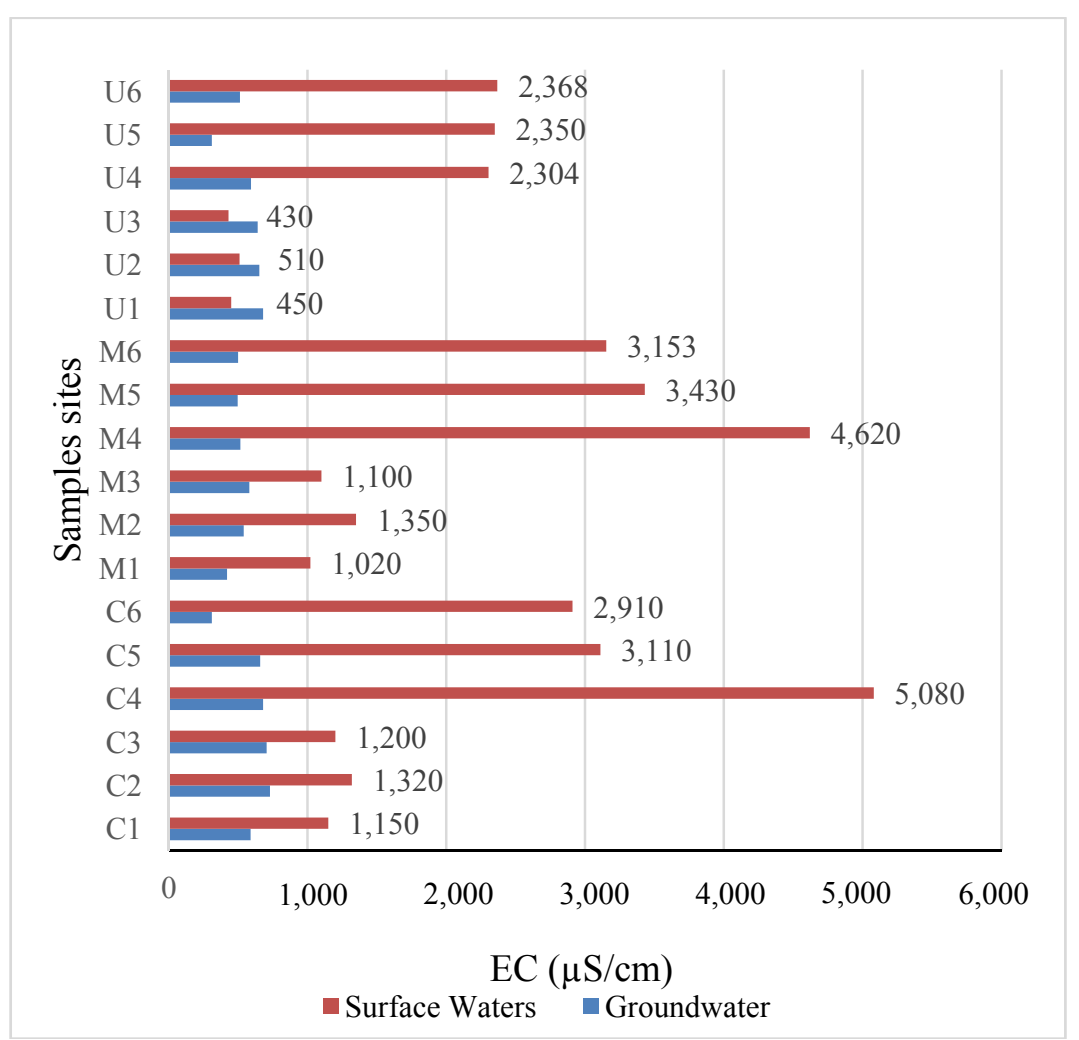

Fig. 3 The values of EC in groundwater and surface waters. 
Table 2 Some physico-chemical properties, concentrations of total $P$ and LAS in surface waters.

\begin{tabular}{|c|c|c|c|c|c|c|c|c|}
\hline $\begin{array}{l}\text { Sample } \\
\text { code }\end{array}$ & Name of sample & Date & $\mathrm{T}\left({ }^{\circ} \mathrm{C}\right)$ & $\mathrm{pH}$ & $\begin{array}{l}\text { Turbidity } \\
\text { (NTU) }\end{array}$ & $\begin{array}{l}\mathrm{EC} \\
(\mu \mathrm{S} / \mathrm{cm})\end{array}$ & $\begin{array}{l}\text { Total P } \\
(\mathrm{mg} / \mathrm{L})\end{array}$ & $\begin{array}{l}\begin{array}{l}\text { LAS } \\
(\mathrm{mg} / \mathrm{L})\end{array} \\
\end{array}$ \\
\hline $\mathrm{C} 1$ & \multirow{6}{*}{ Çerkezköy } & March-2014 & 19.5 & 7.3 & 25.0 & 1,150 & 0.84 & 0.65 \\
\hline $\mathrm{C} 2$ & & April-2014 & 19.4 & 7.3 & 26.5 & 1,320 & 0.80 & 0.62 \\
\hline $\mathrm{C} 3$ & & May-2014 & 19.7 & 7.3 & 22.5 & 1,200 & 0.79 & 0.50 \\
\hline $\mathrm{C} 4$ & & October-2015 & 20.8 & 7.7 & 13.4 & 5,080 & 2.74 & 0.59 \\
\hline $\mathrm{C} 5$ & & November-2015 & 18.3 & 7.8 & 39.3 & 3,110 & 2.36 & 2.38 \\
\hline $\mathrm{C} 6$ & & December-2015 & 19.3 & 7.8 & 31.8 & 2,910 & 3.09 & 1.98 \\
\hline M1 & \multirow{6}{*}{ Muratlı } & March-2014 & 19.0 & 7.3 & 23.0 & 1,020 & 0.90 & 0.45 \\
\hline M2 & & April-2014 & 12.0 & 7.5 & 25.4 & 1,350 & 0.92 & 0.57 \\
\hline M3 & & May-2014 & 20.0 & 7.4 & 21.0 & 1,100 & 0.82 & 0.50 \\
\hline M4 & & October-2015 & 24.0 & 7.9 & 28.1 & 4,620 & 3.51 & 0.014 \\
\hline M5 & & November-2015 & 17.1 & 7.9 & 31.2 & 3,430 & 2.81 & 3.09 \\
\hline M6 & & December-2015 & 19.2 & 7.9 & 32.8 & 3,153 & 2.11 & 1.78 \\
\hline $\mathrm{U} 1$ & \multirow{6}{*}{ Uzunköprü } & March-2014 & 18.5 & 7.4 & 19.1 & 450 & 0.79 & 0.25 \\
\hline U2 & & April-2014 & 19.5 & 7.2 & 22.0 & 510 & 0.81 & 0.30 \\
\hline U3 & & May-2014 & 20.1 & 7.4 & 20.5 & 430 & 0.72 & 0.10 \\
\hline U4 & & October-2015 & 20.9 & 7.9 & 43.6 & 2,304 & 2.56 & 0.022 \\
\hline U5 & & November-2015 & 20.2 & 7.9 & 12.5 & 2,350 & 1.20 & 0.30 \\
\hline U6 & & December-2015 & 19.3 & 8.2 & 29.6 & 2,368 & 1.81 & 2.35 \\
\hline
\end{tabular}

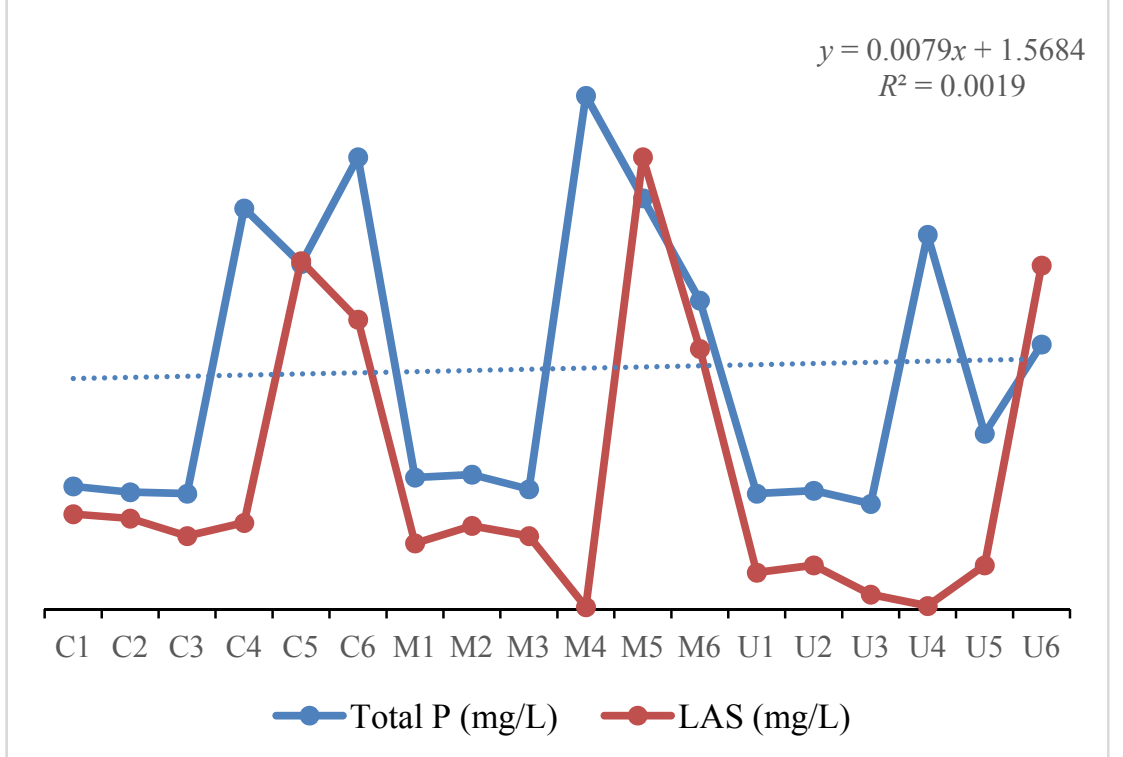

Fig. 4 The relationship between total $P$ and LAS concentration in surface water samples.

Uzunköprü is the site where all the surface waters are collected in Ergene Basin.

The total $\mathrm{P}$ and LAS concentrations of surface waters are generally higher than groundwater. The relationship between concentrations of total $\mathrm{P}$ and LAS is presented in Fig. 4. The total $\mathrm{P}$ concentrations are higher than the LAS concentrations in all surface waters. The highest total $\mathrm{P}$ and LAS concentrations were measured in Muratlı surface waters (M4 and M5) as $3.51 \mathrm{mg} / \mathrm{L}$ and $3.09 \mathrm{mg} / \mathrm{L}$, respectively. It has been observed that the values determined in this study are less than the values of surfactant (0.084-5.592 mg/L) in Gediz River reported by Minareci [18] and they are higher than the values of surfactant (0.003-1.122 mg/L) in Sapanca Lake reported by Macit [19]. In a similar research, the total concentrations of LAS ranged from 
Table 3 Some physical-chemical properties, concentrations of total $P$ and LAS in this study, and comparison with guidelines.

\begin{tabular}{|c|c|c|c|c|c|c|}
\hline Contents & $\mathrm{T}\left({ }^{\circ} \mathrm{C}\right)$ & $\mathrm{pH}$ & $\begin{array}{l}\mathrm{EC} \\
(\mu \mathrm{S} / \mathrm{cm})\end{array}$ & $\begin{array}{l}\text { Turbidity } \\
\text { (NTU) }\end{array}$ & $\begin{array}{l}\text { Total P } \\
(\mathrm{mg} / \mathrm{L})\end{array}$ & $\begin{array}{l}\mathrm{LAS} \\
(\mathrm{mg} / \mathrm{L})\end{array}$ \\
\hline \multicolumn{7}{|l|}{ This study } \\
\hline Groundwater & $17.5-22.8$ & $7.1-8.9$ & $310-729$ & $0.1-3.75$ & $0.01-0.65$ & $0.01-0.37$ \\
\hline Surface water & $12.0-24.0$ & $7.2-8.2$ & $430-5,080$ & $13.4-43.6$ & $0.72-3.51$ & $0.014-2.38$ \\
\hline \multicolumn{7}{|c|}{ Turkish environmental guidelines } \\
\hline Class I & $\leq 25$ & $6.5-8.5$ & $<400$ & - & $<0.03$ & $<2$ \\
\hline Class II & $\leq 25$ & $6.5-8.5$ & $400-1,000$ & - & $0.03-0.16$ & - \\
\hline Class III & $\leq 30$ & $6.0-9.0$ & $1,001-3,000$ & - & $0.16-0.65$ & - \\
\hline Class IV & $>30$ & $>9.0$ & $>3,000$ & - & $>0.65$ & - \\
\hline \multicolumn{7}{|c|}{$\begin{array}{l}\text { Water quality criteria for drinking } \\
\text { water }\end{array}$} \\
\hline EC (1998) & - & $6.5-9.5$ & $<2,500$ & $<1$ & - & - \\
\hline
\end{tabular}

$240 \mathrm{mg} / \mathrm{L}$ to $9,706 \mathrm{mg} / \mathrm{L}$ at the Wilmington and Bryan streams [20].

The comparison of this study results with guidelines is presented in Table 3. When the results are compared with the values stated in the limit of the Turkish Water Pollution Control Regulations, the turbidity values are generally $<1$ in groundwater and they are very high in surface waters; in terms of temperature values, all waters are in I class; in terms of $\mathrm{pH}$ values, the groundwater is in I-III class and the surface water in I class; in terms of EC values, the groundwater is in I-II class and the surface waters in II-IV class; in terms of total $\mathrm{P}$ concentrations, the groundwater is in I-III class and the surface waters in IV class; in terms of LAS concentrations, the groundwater is in I-II class and the surface waters in II-IV class.

\section{Conclusions}

Surfactants are often very potent and also designed to be resistant to biodegradation. This, however, contributes to their environmental pollution. Various approaches have been discussed and applied, including the control of surfactants at source, segregation of sources.

In Ergene Basin, advanced treatment technologies should be applied which also remove surfactants. There is a need to expand on-going scientific research to assess the impact of surfactants, and their metabolites and transformation products on the aquatic environment. The effluent organic matter of treated wastewater needs to be characterized to a greater extent, especially when wastewater is reused for irrigation.

According to the European policy framework, the precautionary principle may be provided in the environment where scientific data do not enable to complete evaluation of the risk because of the possibility of danger to human, animal and plant health.

\section{Acknowledgments}

The authors are grateful to Laboratory of Yeşil Beyaz Quality and Environment for research grants awarded to complete the present study.

\section{References}

[1] Cantarero, S., Camino-Sanchez, F. J., Zafra-Gomez, A., Ballesteros, O., Navalon, A., Vilchez, J. L., Verge, C., Reis, M. S., and Paraiva, P. M. 2012. "Evaluation of the Presence of Major Anionic Surfactants in Marine Sediments." Mar. Poll. Bull. 64 (3): 587-94.

[2] Ying, G. G. 2006. "Fate, Behaviour and Effects of Surfactants and Their Degradation Products in the Environment." Environ. Int. 32 (3): 417-31.

[3] Hodges, G., Roberts, D. W., Marshall, S. J., and Dearden, J. C. 2005. "The Aquatic Toxicity Surfactants to Daphnia magna-A Comparative QSAR Study of Linear Alkylbenzene Sulfonates and Ester Sulfonates." Chemosphere 63 (9): 1443-50. 
[4] Lara-Martin, P. A., Gomez-Parra, A., and Gonzalez-Mazo, E. 2008. "Sources, Transport and Reactivity of Anionic and Non-ionic Surfactants in Several Aquatic Ecosystems in SW Spain: A Comparative Study." Environ. Poll. 156 (1): 36-45.

[5] Mungray, A. K., and Kumar, P. 2008. "Occurrence of Anionic Surfactants in Treated Sewage: Risk Assessment to Aquatic Environment." J. Hazard Mater. 160: 362-70.

[6] Gordon, A. K., Muller, W. J., Gysman, N., Marshall, S. J., Sparham, C. J., O’Connor, S. M., and Whelan, M. J. 2009. "Effect of Laundry Activities on In-Stream Concentrations of Linear Alkylbenzene Sulfonate in a Small Rural South African River." Sci. Total Environ. 407 (15): 4465-71.

[7] Budicania, T. S., Irawan, C., Afriani, K., Foliatini, S. R., and Saksono, N. 2017. "Degradation of Linear Alkylbenzene Sulfonate (LAS) by Using Multi-contact Glow Discharge Electrolysis (m-CGDE) and $\mathrm{Fe}^{2+}$ Ion as Catalyst." J. Environ. Chem. Eng. 5: 2346-9.

[8] Tubau, I., Vazquez-Sune, E., Carrera, J., Gonzalez, S., Petrovic, M., Lopez de Alda, M. J., and Barcelo, D. 2010. "Occurrence and Fate of Alkylphenol Polyethoxylate Degradation Products and Linear Alkylbenzene Sulfonate Surfactants in Urban Ground Water: Barcelona Case Study." J. Hydrol. 383: 102-10.

[9] Eichhorn, P., Rodrigues, S. V., Baumann, W., and Knepper, T. P. 2002. "Incomplete Degradation of Linear Alkylbenzene Sulfonate Surfactants in Brazilian Surface Waters and Pursuit of Their Polar Metabolites in Drinking Waters." Sci. Total Environ. 284: 123-34.

[10] Sakai, N., Shirasaka, J., Matsui, Y., Ramli, M. R., Yoshida, K., Mohd, M. A., and Yoneda, M. 2017. "Occurrence, Fate and Environmental Risk of Linear Alkylbenzene Sulfonate in the Langat and Selangor River Basins, Malaysia." Chemosphere 172: 234-41.

[11] Provincial Environment Directorate of Tekirdağ
Governorship. 2014. Tekirdă̆ Environmental Information Report.

[12] American Public Health Association (APHA). 1998. Standard Methods for the Examination of Water and Wastewater, 20th ed.. Washington, D.C.: APHA.

[13] Barut, Z. 2016. "Investigation of Some Groundwater and Surface Water Resources in Terms of Surfactant Pollution in Ergene Basin." M.Sc. thesis, Graduate School of Natural and Applied Sciences, Namık Kemal University.

[14] ISO 7875-1. 1996. Water Quality-Determination of Surfactants: Part 1, Determination of Anionic Surfactants by Measurement of the Methylene Blue Index (MBAS).

[15] Ministry of Environment and Forestry. 2012. Turkish Standard Regulation of Water Pollution Control.

[16] EC Drinking Water Directive. 1998. Water Intended for Human Council Directive 98/83/EC.

[17] Jurado, A., Vazquez-Sune, E., Carrera, J., Lopez de Alda, M., Pujades, E., and Barcelo, D. 2012. "Emerging Organic Contaminants in Groundwater in Spain: A Review of Sources, Recent Occurrence and Fate in a European Context." Sci. Total Environ. 440: 82-94.

[18] Minareci, O. 2007. "Investigation of Surfactant Pollution in Gediz River.” Ph.D. thesis, Graduate School of Natural and Applied Sciences, Celal Bayar Üniversity.

[19] Macit, A. K. 2010. "Determination of Microbiological and Chemical Pollution Levels of Sapanca Lake (Adapazar1)." Master thesis, Institute of Science and Technology, Marmara University, Istanbul.

[20] Sanderson, H., Dyer, S. D., Price, B. B., Nielsen, A. M., Van Compernolle, R., Selby, M., Stanton, K., Evans, A., Ciarlo, M., and Sedlak, R. 2006. "Occurrence and Weight-of-Evidence Risk Assessment of Alkyl Sulfates, Alkyl Ethoxysulfates, and Linear Alkylbenzene Sulfonates (LAS) in River Water and Sediments." Sci. Total Environ. 368: 695-712. 